\title{
The core - the periphery in global capitalism: from hegemony to multipolar order
}

Keywords: imperial world order, multipolar world order, empire, neoliberal capitalism, planetary crisis, USA, China

\begin{abstract}
The article analyzes the present order, called neoliberal globalization. It serves American corporations from the arms, mining, financial and ICT sectors to accumulate the capital. They made Wall Street the financial center of the world where the surplus of Europe, Japan and Latin American is transformed into the American bonds. This order is embedded in the institutions created and steered by the American state. The competitive advantage in this phase of the evolution of capitalism is given not only by control over so-called intellectual property but also by conquering a possibly large market. That is the reason for the competition between huge mega-corporations such as American GAFA or Chinese BATX. Capitalism is affected by the planetary crisis. A decline of the economic growth rate will take place as a result of natural limits from 3\% to the anticipated 1\%, including a decreased productivity of the computer revolution. Mechanisms of the functioning of the world economy will change: reconstruction of energy industry and transport, pressure on recycling of minerals, transformation of the labour market together with the use of robotics and artificial intelligence, the end of consumptionism. The daily issues include
\end{abstract}

* ORCID ID: https://orcid.org/0000-0003-2101-5060; professor at the Faculty of Political Science and International Studies. He specializes in the methodology of social sciences, the theory of politics and global studies. He published Understanding Politics. Theory, Procedures, Narratives, Peter Lang Edition, Frankfurt am Main 2017; Elsevier's Slaves. The Washington Consensus in the Social Sciences?, «Society Register» 2020, vol. 4, No. 4. Email: tklementewicz@uw.edu.pl 
the problem of supplementing economic globalization with a political control mechanism and including a new civilizational power, which China is becoming. The latter opt for a multipolar order, where local civilizations will preserve their separate character and where they will be able to create a system of supplying their economies with deficit raw material and outlets but without military bases and without following the USA in recognizing certain areas to be the "zones of vested interests". The world will be different but will it be worse?

\section{Who does the supreme authority over the world system of global capitalism belong to?}

In universal history the economically dominating societies used their states to shape the international order in the best way serving the needs of their economic elites. That was at the stage of merchant and industrial capitalism in the following sequence: Venice, Genoa, the Netherlands, England and the USA ${ }^{1}$. After World War II, The American state, like all empires in history, became an instrument in creating the world order in the interest of its own corporations. After the war that order served the expansion of the American industrial sector developed for the needs of the military effort during the war. Initially, it was a "soft" economic and political expansion as it was mitigated by the Bretton Woods system based on the convertibility of the dollar for gold according to an established parity, with a mechanism controlling the capital flow and the equilibrium of foreign trade balances ${ }^{2}$. In that period transfer of profits brought by American direct investments in the peripheries was three times as big as the outlays ${ }^{3}$. The present order, called neoliberal globalization, was created by the American power at the turn of the 1970's and the 1980's, beginning with the decision made by president R. Nixon on unpegging the dollar exchange rate. This order serves the American corporations from the arms, mining, financial and ICT sectors. According to Yanis Varoufakis, they made the States a Global Minotaur turning

1 G. Arrighi, Adam Smith in Beijing. Lineages of Twenty-Firth Century Capitalism, Verso, London 2007, p. 231.

2 G. Monbiot, Neoliberalism - the ideology at the root of all our problems, https://www.theguardian. com/books/2016/apr/15/neoliberalism-ideology-problem-george-monbiot (05.04.2021).

3 H. Magdoff, The Age of Imperialism. The Economics of U.S. Foreign Policy, Monthly Review Press, New York 1969, p. 198. 
the world surplus into American bonds ${ }^{4}$. They are a substitute of savings security for the rentiers of the whole world. This order is guarded by sailing fortresses, F-16 and a newer generation F-35 planes as well as the intelligence penetrating the cabinets of even allied governments. This is the reason why many researchers think that the mechanisms of global capitalism are governed from the back seat by the politicians representing corporations, especially the American Treasury Department ${ }^{5}$. That is why global capitalism is not of supranational character but it is rooted in the institutions established and controlled by the American powerful state $^{6}$. In this order the states which independently shape their national strategy and want to preserve a civilizational and political independence are specific black holes. Russia is in the crosshairs as it has not bent into the West as the only one in history. A few other countries are going their own ways, e.g. China, Iran, India and Bolivia.

The evolution of capitalism resulted in the appearance of a new field of capital accumulation. In cognitive capitalism corporations (their main stockholders, shareholders, administrators, "investors" - frequently, so-called petty savers) control only inventions, buy up start-ups, have annuities from so-called intellectual property rights: patents, trademarks, copyrights to replicators (digital patterns of products) and robots. The branches where the incomes bring intellectual property rights constitute $35 \%$ of the American GDP 7 . So-called cognitive capitalism earns on personalized advertisements using digital platforms, like Uber or Airbnb. But it "dedicates" the production of goods bringing profit to the cheap workforce in China or Central Europe. The contemporary Fords do not build factories. Today, the assembly line goes round the globe, the container is replaced by a conveyor belt and only the role of the distribution system (vide Amazon) and e-trade is even greater. Blown companies predominate in globalized economy. The center includes the managing headquarters and, possibly, the departments responsible for research and developmental work. The center only coordinates the network of suppliers and sub-suppliers winding up around the globe. A production chain appears whose first link is placed on the Chinese coast or in

4 Y. Varoufakis, Globalny Minotaur. Europa, Ameryka i przyszłość światowej gospodarki, Warszawa 2015, pp. 121-123.

5 E.g. M. Mann, Incoherent Empire, Verso, Londyn 2003, pp. 49 ff.

6 A. Callinicos, Imperialism and Global Political Economy, Polity Press, Maiden MA. 2009, p. 196/197 and F. Ilkowski, Imperializm kapitalistyczny we wspótczesnych ujęciach teoretycznych, Toruń 2015.

7 P. Frase, Cztery przyszłości. Wizje świata po kapitalizmie, Warszawa 2018, p. 70. 
Central Europe. In this way, outsourcing of industrial production has taken place since this operation makes it possible to lower labour costs and thus achieve extraordinary profits. A reserve army of labour can even comprise 2.4 billion people, according to the estimates of John Bellamy Foster ${ }^{8}$. Although this refers to the products that are technological miracles, like iPhone, but the assembly of their separately produced parts takes place faster and faster with the skilful hands of trained inhabitants of the Chinese province. Factories, or rather assembly plants, where the gadgets of the information society are produced, are the property of local producers but their margin is small. As estimated by Foster, the cost of the Chinese workforce involved in producing and assembling iPhones in 2010 was $1.8 \%$ of the finale sale price ${ }^{9}$. The creation of such chains of production and services required computers, a telecommunication network, modern logistics, especially containerization of transport and greater access to qualified and at the same cheap workforce. Captains of industry were replaced by owners of financial capital: shares in corporations, parcels of shares, office spaces, bonds of countries in debt, shares in investment funds. The final subject of the system power in this situation is an invisible parliament of investors. By means of central banks and their financial policy, the states protect the value of money, mainly caring about a balanced budget. In the EU countries, the Central Bank, which is independent from governments, directly guards the stability of money. A significant element of this puzzle are tax havens. According to a report by OXFAM, 26\% of gains of European banks, which constitutes Euro 25 billion yearly and 12\% of their transactions, are booked in tax havens. This is a mechanism of avoiding settling tax returns with the domestic tax office. For each 100 Euros of bank gains, 42 Euros end up in a tax haven and 19 outside of it. A worker produces the income of Euro 171000 in a tax haven, while at home only Euro 45000 (e.g. employees of Barclays bank in Luxembourg are 348 times more "productive"). Banks "earn" trillions in havens and millions at home. Only in Ireland and Luxembourg they achieved 29\% of the incomes. They include the top English, French, German and Dutch banks, e.g.

8 J.B. Foster, Nowy imperializm zglobalizowanego kapitalu monopolistyczno-finansowego. Wprowadzenie, [in:] G. Konat, P. Wielgosz (eds.), Realny kapitalizm. Wokót teorii kapitatu monopolistycznego, Warszawa 2018, p. 108. It is the main source of an extraordinary income (monopoly profit, additional) in the past drawn from colonies. Lenin considered it the basis of modern capitalism. Cf. W. Lenin, Supplementary Theses, www.revolutionarydemocracy.org (04.04.2021).

9 Ibidem, p. 110. 
Santander, Nordea, UniCredit etc. ${ }^{10}$ Another report confirms the process of income defiscalization. In $201540 \%$ of incomes by international companies went to tax havens. ${ }^{11}$ At the same time the average tax rate decreased from 49\% to 24\%. President Donald Trump lowered income taxes in the USA from $32 \%$ to $21 \%{ }^{12}$.

Conquering the possibly largest market gives a competitive advantage at the stage of global capitalism. That is why huge mega-corporations such as American GAFA (Google, Apple, Facebook, Amazon) or Chinese BATX (Baidu, Alibaba, Tencent, Xiaomi) compete with each other. The power of intellectual property of patents is linked here with financial resources. Thanks to innovative annuity, high turnover, high margins and the market position, the "leading" firm has considerable liquidity reserves and easy access to bank credits so it takes over a big part of the surplus produced in global economy. The price of such a firm's product includes as much as 75\% of "non-material assets": payment for research, patent, project, marketing strategy, etc. ${ }^{13}$ These tasks are performed by the so-called staffs, specialists, middle class. Thanks to the domination on the market, the firm buys up the start-ups, performs fusions and takes over the competitors. The present capital concentration consists in controlling and coordinating production and turnover of high-tech products (with a few exceptions of mining or arms industries). Here, the characterization of capitalism as a multi-storey construction where "a constant game of investing" takes place is confirmed ${ }^{14}$. The lower floors are occupied mainly by family businesses in agricultural production, services, real estate development business and window production - like 2.3 million of Polish mini-firms. The higher places, on the other hand, are taken by increasingly longer chains of production and exchange created by large corporations. They implement innovative products based on the achievements of natural and technical sciences. The profits of 500 largest mega-corporations approach $30 \%$ of the world's GDP15.

10 Oxfam 2017, Opening the Vaults: the use of tax havens by Europe's biggest banks, www. org./files/bp-opening-vaults-banks-tax-havens-270117-en_o.pdf (04.04.2021).

11 Th.R. Torslov, L.S. Wier, G. Zuckman, The Missing Profits of Nations, NBER Working Paper No 24701, 23.07.2018, vox.eu. 2018, online appendix, April 2020 (04.04.2021).

12 S. Gandel, Tax Cut Is Better (for Companies) and Worse (for Everyone Else), 14 January 2019, 10:00 CET, https://www.bloomberg.com/opinion/articles/2019-01-14/trump-tax-cut-turnsout-both-better-and-worse (04.04.2021).

13 W. Szymański, Niepewność i niestabilność gospodarcza. Gwałtowny wzrost $i$ co dalej?, Warszawa 2011, pp. 195-199.

14 F. Braudel, Dynamika kapitalizmu, Warszawa 2013, p. 74.

15 J.B. Foster, Nowy imperializm..., p. 118. 
Therefore, this position is close to gaining 'the control stock' over the world economy and - as a consequence - over the states, the universities financed by the former and the future of civilization. Now the capital managers from the Silicon Valley reserve for themselves the decision about the range of using artificial intelligence, people's privacy or genetic modifications. They have replaced national parliaments, public debate or universities in this task.

Energy industry and minerals became the next field of financial accumulation. This is so-called "new extremism". Besides hydrocarbons it is now metals of rare soils, especially lithium, which become a new area of competition between corporations and states which safeguard the former (vide Nord Stream 2 and Bolivian deposits of lithium). Areas of arable land are also used by plantation agriculture of large agro-business corporations to achieve huge margins of profit. To give an example, in 2007 Monsanto increased their incomes by $44 \%$ on the coffee market, where there are 25 million small producers. Five billion dollars was left in their pockets and the remaining 70 billion went to the North to the oligopoly concerned with the processing and distribution of this raw material ${ }^{16}$. Neoliberal transformations of the Global South led to the shaken nutrition security of mankind since the place of cereal cultivations was taken by the "production" of soybean for cattle breeding or for components of bio-fuels ${ }^{17}$.

The neoliberal Leviathan also subjected science to the needs of corporations. First it introduced management at universities in accordance with the ideal of an supervising state in order to enforce transparency, accountability and effectiveness. In a word, value for money. Hence a big role of the sociotechnics of the audit and practices of measuring academic work. Domestic bureaucracies managing science and higher education (in Poland, Gowin's reform for example) aim to direct researchers and universities towards the creation of knowledge which can be commoditized and privatized, though on higher levels of the circulation of ideas and innovations. Science is expected to bring profits; if not from research and implementations themselves, then at least from the turnover of scientific information and exploitation of scientists as authors

16 Cf. R. Palberg, Food Politics. What everyone needs to know, Oxford University Press 2010, pp. $127-138$.

17 M. Mazoyer, L. Roudart, A History of World Agriculture from the Neolitic Age to current Crisis, Monthly Review Press, New York 2006, pp. 444-468; W. Bello, Wojny żywnościowe, Warszawa 2011, pp. 54-62; T. Weis, Światowa gospodarka żywnościowa. Batalia o przyszłość rolnictwa, Warszawa 2011. 
of publications. As a result, the model of a research university created in the USA makes it possible for corporations to capture the knowledge financed from public funds ${ }^{18}$.

Four decades of neoliberal globalization, or more exactly, oligarchicfinancial capitalism, brought an increase of inequalities within particular societies as well as between the regions of the world. As a consequence, social movements, both leftist and rightist, were revived. Inequalities in the division of the social wealth and their social and economic source attracted the attention of all social sciences. The debate was initiated by Thomas Piketty's book "Capital in the Twenty-First Century". The French economist claims that the rate of return from the capital (bank deposits, shares or dividends) is higher than the rate of economic growth. As a result, disproportions in the division of incomes and later properties increase. On the world level, in 2010 a permil of the wealthiest possessed $20 \%$ of the total property, $1 \%$ possessed about a half of the world's wealth (then it was 45 million who possessed, on average, the property of Euro 3 million, which is 50 times more than an average property), and a $10 \%$ group of the richest managed between $80 \%$ and $90 \%$ of the whole property. In this situation the people from the bottom must be satisfied with less than $5 \%$ of the whole ${ }^{19}$. What is worse, considerable disproportions also occur between the regions of the world: $80 \%$ of the global inequality of income is accounted for by the country, and not the class (B. Milanović) ${ }^{20}$. In this way, a class of global rentiers, as it was called by Foster, emerged which oscillates around 300 million owners of shares (about 5\% of the world population). Its historical existence depends on the financial capital circulating in the world economy, and - more directly - on the control of the financial market and annuities that it brings. Corporations, which create these incomes, have their seats in only eight countries and they operate within the whole economic space of the world but their ownership structure is characterized by a clear national affinity, as is stated by Atilio Boron ${ }^{21}$. They are served by international and local classes of specialists: bank economists, lawyers and brokers. John Perkins, a hitman, as he calls himself, estimates their

18 T. Klementewicz, Elsevier's Slaves: the Washington Consensus in the Social Sciences?, «Society Register» 2020, No 4, pp. 183-208. https://doi.org/10.14746/sr.2020.4.4.09 (03.04.2021).

19 T. Piketty, Kapitat w XXI wieku, Warszawa 2015, p. 540.

20 B. Milanovic, Global Inequality. A New Approach for the Age of Globalization, The Belknap Press of Harvard University Press 2016, p. 128.

21 B. Milanovic, Empire and Imperialism. A critical Reading of Michael Hardt and Antonio Negri, Zed Press 2005, p. 46. 
number at several thousand ${ }^{22}$. And it is also them who are the beneficiaries of the system.

The situation has been changed by 800 trillion inhabitants of China, who have got out of extreme poverty since the Chinese market became accessible for foreign and local firms. At the same time, thanks to the growing technological autonomy, accumulated savings and investments all over the world, the Chinese economy is supported by the state which organizes new markets of outlet, supply of energy and raw materials for their domestic companies. It collides with the interests of Western corporations in many fields. This gives rise to competition and attempts to correct the existing order, which also includes influences on the functioning of multilateral organizations to make them consider the interests of Chinese economy in the proper degree.

\section{Twilight of the American center of neoliberal capitalism}

American politicians, supported by university economists and financial institutions accompanied by media commentators, implemented the model of capitalism subordinating nature, work and human life to the logic of profit. The recipe prepared by neoclassic economists was brought to life by successive presidents: departure from the Bretton Woods system in 1971 resulting in the loss of control over the capital flow (R. Nixon), tax reforms (R. Reagan), and repealing the GlassaSteagall Act, which separated commercial banking from investment banking (B. Clinton). The American society became a specific laboratory of entrepreneurship and free market and an empirical demonstration of the doctrine of economic liberalism for the welfare states, which J.M. Keynes seduced. It was no more Roma causa but the laureates of the so-called economic Nobel. The American lifestyle became soft-power: "a cultural weapon of mass destruction", according to the definition by Andrzej Szahaj. It is Americans who create the world pop culture.

The increasing cultural hegemony of the USA proceeds along with the erosion of the economic power and a civilizational collapse of this model of society. Although Americans make up 4.5\% of the world population, according to the up-dated data of WTO, every fourth victim of COVID-19 is an inhabitant of this country and this happens in a society which has almost 65 thousand dollars per capita. It is for the next time

22 J. Perkins, Hitman. Nowe wyznania ekonomisty od brudnej roboty, Warszawa 2017, p. 298. 
that the dialectics of decadence is confirmed: before a fall agonal patterns flourish.

The measure of effective individualistic life strategy in the American society is the bank account. On the basis of his studies Arlie Russell Hochschild argues that the inhabitants of the Deep South in the USA believe - against the empirical falsification - that "free market is an unshakeable ally of good citizens queuing to have their American dream fulfilled" 23 . They are convinced that their American dream about a house in the suburbs, a well-paid job would come true if the intruders from all over the world whose skin is a palette of colours did not jump the queue. The federal government, which supports the shiftless, who are without any ambitions and will to succeed, is standing on the way. Thanks to such processing of the mind, the social protest changed in his country into a cultural war, into a war to preserve the "conceived life", the traditional family, and especially to ensure security to the latter owing to the possession of guns.

The Gini index is close to 0.5 , which means big differentiation of incomes and property. Meritocracy are graduates of prestige universities. To get there, the system of scholarships and loans is not enough; you have to choose the family well. High level education is costly from the lowest level of the education system. Not surprisingly, it can be afforded by 14 times more sons and daughters whose parents are placed in the group of $2-\%$ of the wealthiest than the $20 \%$ of the poorest. That is why, as a consequence, only $11 \%$ of those born in the latter group manage to get to the financial elite whose incomes belong to the upper $20 \% 24$.

A shareholder and a speculator predominate in the economy and hence the domination of the financial sector and the capital market. It handles not only speculation with securities but also with oil, food, commercial real estates, industrial enterprises, which can be bought, sold and closed up - depending on the stock price and business strategy. The short-term profitability justifies pumping 15 million liters of water into one operation of unconventional fracking to squeeze gas from a deposit of shale ${ }^{25}$. Even if the society consumes a quarter of the energy produced in the world, the "American life style is non-negotiable", as was announced George Bush in Rio de Janeiro during the climate change conference.

23 J. Perkins, Obcy we wtasnym kraju. Gniew $i$ żal amerykańskiej prawicy, Warszawa 2017, p. 241.

24 E. Eckholm, Higher Education Gap May Slow Economic Mobility, «The New York Times» 20 February 2008, https://www.nytimes.com/2008/02/20/us/20mobility.html (02.04.2021).

25 U. Bardi, Wydobycie. Jak poszukiwanie bogactw mineralnych pustoszy nasza planete, Warszawa 2018, p. 84. 
A model of business followed worldwide was created by Walmart. It employs 2 million workers, including female cashiers who earn starvation wages while others are responsible for the costs of living for them. The employees of this giant of large-area trade take advantage of state schools, police protection, public roads, public systems of social care. These goods are secured for them by others: American tax-payers pay extra 3 to 6 thousand dollars annually for each low-paid cashier from Walmart.

A permanent tendency is that work productivity and the median wages split up. The former has increased by $90 \%$ in the last 40 years, whereas the latter - only by $10 \%$. The American golden boys earn 13 million Euros annually and this amount is composed of stock options and allocation of free shares, which frequently makes three times as much as the basic wages. They aim at short-term financial profits (market to market) instead of creating fixed assets and work places. In the middle 1960's the president of a corporation earned 24 times as much as their worker in the production sector. Nowadays it is 185 times more. According to the analysis of the Nobel Prize winner Angus Deaton, in 2015 the Americans at the bottom of the social ladder lived at the level of $36 \%$ of the official poverty threshold while the working poor make as much as $21 \%$ of the total employed people. It does not surprise that $14 \%$ of Americans, which is about 40 million, need so-called food stamps ${ }^{26}$. Half of the workers do not have sufficient incomes to pay pension contributions. And two thirds below 40 years of age do not have any pension savings. As a result, about 30 million Americans are not insured and just a few badly-paid occasional jobs may not be enough to live a month without the support of social care $^{27}$. Afro-Americans are in the worst situation. Almost half of them do not have permanent employment. They make up $46 \%$ of prisoners. $23 \%$ of black men between 20 and 30 are in prisons or under court control ${ }^{28}$. This is also the effect of ghettoization and a low level of state-owned schools. Privatization comprises more and more public services.

In 2015 the upper $20 \%$ of the population reached the average income which was 8.3 times higher than the $20 \%$ of the poorest (in Germany 4.4

26 A. Deaton, Wielka ucieczka. Zdrowie, bogactwo i źródła nierówności, Warszawa 2016, pp. 201, 224.

27 E.R. Berchik, E. Hood, J.C. Barnett, Health Incurance Coverage in the United States: 2017, September 12, 2018, https://www.census.gov/library/publications/2018/demo/p60-264.html (04.04.2021).

28 Z.M. Kowalewski, RAP między Malcolmem X a subkultura gangowa. Naród Islamu w czarnej Ameryce, Warszawa 2020, p. 42. 
times higher, in Denmark only 3.7 times). In the same year, $17 \%$ of the American society lived below the relative poverty limit, in Germany 9.5\% and in Denmark 5.5\% ${ }^{29}$. The country also has its tax havens in its territory and there the already low-taxed rentier gains and incomes disappear like in a black hole. However, the state still performs an important role in economy. Using the war budget, it corrects budget deficits between particular states, locating armaments plants in less dynamic ones. A big role in initiating and financing research and development work is played by the Pentagon and its agency DARPA (Defense Advanced Research Project Agency).

\section{Planetary crisis and reconfiguration of global capitalism - the Chinese strategy of limiting the American hegemony}

According to the prognosis of Joseph Schumpeter from 1942, capitalism is sinking due to its historical success. The size of the production apparatus cannot fit onto the only planet which is so far accessible to humans. The industrial civilization, though saturated with technologies of information processing, continues to process gigatons of atoms; the sector of so-called technological corporations produces only $10 \%$ of GDP and employs $5 \%$ of the workforce. The permanent game of investing and consuming could go on ceaselessly if mankind had a few planets to use. A decrease of the rate of economic growth will take place from 3\% to the forecast $1 \%$ as a result of natural limits. The productivity of the computer revolution is also decreasing, since 2010 remaining at the level of $0.5 \%$ in the USA. The mechanisms of the functioning of this economy will change: rebuilding of power engineering and transport, emphasis on recycling of minerals, changed market following the use of robotics and artificial intelligence, the end of the concept of life and usage, i.e. consumptionism. Different scenarios of these changes are possible: from extremism to gradual socialization of the production apparatus aimed to subordinated it to the arithmetic of social needs instead of the logic of profit ${ }^{30}$.

29 After: The World Bank, Nearly Half the World Lives on Less than \$5.50 a Day, October 17, 2018, https://www.worldbank.org/en/news/press-release/2018/10/17/nearly-half-the-worldlives-on-less-than-550-a-day (04.04.2021).

30 Cf. M. Klare, Rising Powers, Shrinking Planet. How scarce energy is creating a new world order, A Oneworld Book 2008, pp. 259-261. 
The daily problem is to supplement economic globalization with the political mechanism of control and to involve a new civilizational power, which is China. The Chinese experiment is to combine the market advantages with the coordinating role of the state remaining under the control of contemporary Mandarins. They are the staffs of the Chinese Communist Party, usually graduates of the faculties of management.

Firstly, the state preserved relative autonomy in relation to the domestic business. It is also beyond the reach of global governance under the aegis of the USA; it is limited neither by the mechanism of debt nor guarantees of military security from the American patron. The country of the Han dynasty has used the earlier experiences of Japan, South Korea and Taiwan: the experiences with the strategic control of the process of modernizing the economy and controlling the capital flowing in from the West. A hundred years of Western companies and states penetrating the Chinese economy has taught caution. It ignored the commandment coming from Washington and concerning the minimal state, deregulation of the financial sector and privatization of the public sector. It followed the path of rational authoritarianism ${ }^{31}$. It complemented high accumulation with the proper macro-economic policy: no convertibility of the yuan, control over the investments of foreign capital through the establishment of special zones and companies with the share of the Chinese capital limited the inflow of portfolio capital. This effective economic policy of China was expected to be paralyzed by the Trans-Pacific Partnership (TPP) ${ }^{32}$. It would be forced to participate in the world economy according to the conditions established by the USA - using international organizations, mainly WB, IMF, WTO. It would also have to make its savings available to the financial sector of the West. Here, president Trump himself, who refused to sign it, turned out to be China's friend. In this situation neoliberal globalization continued to make a fast growth of the Chinese GDP possible. Therefore, China went along another path than the old societies of real socialism in Europe. They fit themselves into the reality shaped in the interests of large corporations by giving away the banking sector, interior market, depriving themselves of industry developed with the effort of many generations ${ }^{33}$.

31 Minqi Li, China and the Twenty-First Century Crisis, Pluto Press 2016, p. 7.

32 TPP: What is it and why does it matter?, BBC News, 23 January 2017, https://www.bbc.com/ news/business-32498715 (04.04.2021).

33 More in: A. Madariaga, Neoliberal Resilience: Lessons in Democracy and Development from Latin America and Eastern Europe, Princeton University Press 2020, pp. 8-9. 
Secondly, public does not mean nobody's. The Chinese state questioned the conventional wisdoms about the relation between ownership and entrepreneurship. Scientists representing the theory of public choice and the Austrian school in economy link entrepreneurship with private ownership. That is why it seemed impossible to combine competitive market economy with common or state-owned property. However, lone wolves of business and mini-companies do not operate in contemporary capitalism. On the other hand, there are huge organizational giants, with a complex structure of ownership, employment relations and the ladder like management. Around them a swarm of investors, lenders and speculators is moving. Their environment comprises banks, investment funds and pension funds. This is a huge machinery to handle the money capital, financial products, credits and debts. This machinery is operated by professionals, the same as those who manage public companies or banks. They do not operate their own assets, e.g. on the American market they constitute about $80 \%$ of those institutions' functionaries, as reported by Jacek Tittenbrun ${ }^{34}$. Besides, the information that shapes their decisions is provided by commodity markets, which are additionally incomplete. They do not evaluate natural goods (water, loss of arable land, contaminated oceans) and they ignore the needs of future generations. The kind of ownership is of little importance. Here, professional managers predominate who rarely pay for their mistakes like during the crisis of 2007/2008. In this situation the measure of the effectiveness of the choice of goals and strategies to realize them in public firms can be intersubjective measurable social preferences such as the quality of life or health as well as the necessity to finance from public funds the public services which secure them. Whether it is a domestic or a foreign company, the basis of their extraordinary profits is cheap workforce, mainly composed of migrants from the province. Internal consumption already makes up $43.4 \%$ of GDP, while investments 49\%. China spends $2.3 \%$ of its GDP on developmental research. It also possesses large currency reserves, at present estimated at more than 3.3 trillion dollars, including 40\% in American securities. The growth rate in 2018 was 6.6\%, profitability of firms was $20 \%$. The Gini coefficient is 0.5 , which testifies to a large range of incomes and properties ${ }^{35}$. The COVID-19 pandemic temporarily weakened the pace of economic growth.

34 A. Madariaga, Gospodarka w spoteczeństwie. Zarys socjologii gospodarki i socjologii ekonomicznej w ujęciu strukturalizmu socjologicznego, Poznań 2012, p. 200.

35 sciencemag.org/news/2018/10/surging-rd-spending-china-narrows-gap-united-states (04.04.2021). 
Thirdly, is it another world empire or the establishment of a functional form of the world leadership? China, like all leaders of capital accumulation so far, is creating a wide back-up for its firms: outlet markets, supply of raw materials and energy. China faces a lot of problems: ageing of the society and the consequent loss of the workforce as well as an increase of the demographic dependency ratio, still present corruption, deficit of arable land, a critical water balance, trade and fuel supplies across the Strait of Malacca, separation from "brothers" from Taiwan, American aircraft carriers on the South China Sea, a lack of social insurances, exploitation of the workforce resembling that in the $19^{\text {th }}$ century capitalism of manufactures and early factories. Nowadays the so-called Asian values are replaced by the "faith in money". Individualistic strategies of getting rich and striving at material wealth and luxury, which ensure large incomes appear. The time of ruthless competition in human relationships and - as a consequence - indifference to common goals came ${ }^{36}$.

Having considerable surpluses, the Chinese state is building the infrastructure reconstructing the old Silk Roads in order to connect the ends of Eurasia; it does the same in Africa and partly in South America - looking for minerals, oil, arable land everywhere, at the same time replacing European and American firms. It would like to exchange its surpluses in American bonds for production assets, especially of firms possessing modern technologies, including European ones. It reminds the core countries of the times of exporting their capitals in the period when the European leaders of entrepreneurship were coming out of the great depression in the years 1873-1886, and after World War II the world expansion of the USA. Hence an easy association with imperialism and the fear of "the Thucydides trap", that is the war for the world order adjusted to the needs of domestic capital. Analogies are mainly seen by geo-politicians and geo-economists. They look at history as the nations' struggles for enormous space, whether it be the Heartland of Eurasia, or the Rimland of the oceans, or - soon the cosmos conquest ${ }^{37}$. Meanwhile it is not nations but corporations which create the world order using the political elites running the states. The existing order serves western corporations to enable them easy purchase of raw materials and workforce plus, additionally, access to the absorbent markets. What is more, through the regional stock exchanges the world surpluses from Europe,

36 Pun Ngai, Pracownice chińskich fabryk, Poznań 2010.

37 B. Góralczyk, Wielki renesans. Chińska transformacja i jej konsekwencje, Warszawa 2018. 
Asia and Latin America ultimately find their way to Wall Street. Here again they are miraculously transformed into American bonds and other financial products.

China has a different vision. It wants to create a system of common responsibility for the world affairs. Therefore, it opts for a multipolar order, where local civilizations preserve their separate character and where it will be able to establish a system of supplying its own economy in deficit raw materials and market outlets but unlike the USA without considering some areas to be "the zones of vital interests" (the Near East, and earlier Latin America). The world will be different, but will it be worse?

If we consider the society which emerged over the ocean, its relation to the exploitation of raw materials, level of energy consumption, enormous differentiation of incomes and properties, nihilistic attitude to the climate protection, level of armaments, development of new technologies thanks to the Pentagon, which are potentially always of military use - all this leads to giving up the American vision of the world order. Also EU should start looking for its own way to the mutually beneficial shape of the economic and political space in Eurasia and the location of Russia and China in it. Europe has a competitive industrial complex which was created in Central Europe by Germany although the former is dependent on Chinese companies and cheap labour of male and female Chinese people. The value of only the German car export to China reaches 1.4 trillion dollars, including the subassemblies produced in Poland ${ }^{38}$. EU is facing the necessity of its own estimation of China and its own military and energetic security in the world of the shrinking economic growth.

\section{Bibliography}

Arrighi G., Adam Smith in Beijing. Lineages of Twenty-Firth Century Capitalism, Verso, London 2007.

Bardi U., Wydobycie. Jak poszukiwanie bogactw mineralnych pustoszy nasza planete, Warszawa 2018.

Bendyk E., W Polsce czyli wszędzie. Recz o upadku i przyszłości świata, Warszawa 2020.

Boron A., Empire and Imperialism. A Critical Reading of Michael Hart and Antonio Negri, Zed Press 2005.

Braudel F., Dynamika kapitalizmu, Warszawa 2013.

Callinicos A., Imperialism and Global Political Economy, Polity Press 2009.

Deaton A., Wielka ucieczka. Zdrowie, bogactwo i źródła nierówności, Warszawa 2016.

38 G. Kołodko, Czy Chiny zbawiq świat?, Warszawa 2018, p. 20. 
Foster J.B., Nowy imperializm zglobalizowanego kapitału monopolistyczno-finansowego. Wprowadzenie, [in:] G. Konat, P. Wielgosz (eds.), Realny kapitalizm. Wokót teorii kapitału monopolistycznego, Warszawa 2018.

Frase P., Cztery przyszłości. Wizje świata po kapitalizmie, Warszawa 2018.

Gordon R.J., The Rise and Fall of American Growth: the U.S. Standard of Living since the Civil War, Princeton University Press 2017.

Góralczyk B., Wielki renesans. Chińska transformacja i jej konsekwencje, Warszawa 2018.

Hochschild A.R., Obcy we własnym kraju. Gniew i żal amerykańskiej prawicy, Warszawa 2017. Ilkowski F., Imperializm kapitalistyczny we wspótczesnych ujęciach teoretycznych, Torun 2015.

Klare M., Rising Powers, Shrinking Planet. How scarce energy is creating a new world order, Oneworld Book 2008.

Klementewicz T., Elsevier's Slaves: the Washington Consensus in the Social Sciences? «Society Register» 2020, No. 4, https://doi.org/10.14746/sr.2020.4.4.09

Kołodko G., Czy Chiny zbawia świat?, Warszawa 2018.

Kowalewski Z.M., RAP między Malcolmem X a subkultura gangową. Naród Islamu w czarnej Ameryce, Warszawa 2020.

Madariaga A., Neoliberal Resilience: Lessons in Democracy and Development from Latin America and Eastern Europe, Princeton University Press 2020.

Magdoff H., The Age of Imperialism. The Economics of U.S. Foreign Policy, Monthly Review Press 1969.

Mann M., Incoherent Empire, Verso 2003.

Mazoyer M., Roudart L., A History of World Agriculture from the Neolitic Age to current Crisis, Monthly Review Press 2006.

Milanovic B., Global Inequality. A New Approach for the Age of Globalization, The Belknap Press of Harvard University Press 2016.

Palberg R., Food Politics. What everyone needs to know, Oxford University Press 2010.

Perkins J., Hitman. Nowe wyznania ekonomisty od brudnej roboty, Warszawa 2017.

Piketty T., Kapitat w XXI wieku, Warszawa 2015.

Szymański W., Niepewność i niestabilność gospodarcza. Gwałtowny wzrost i co dalej?, Warszawa 2011.

Tittenbrun J., Gospodarka w społeczeństwie. Zarys socjologii gospodarki $i$ socjologii ekonomicznej $w$ ujęciu strukturalizmu socjologicznego, Poznań 2012.

Varoufakis Y., Globalny Minotaur. Europa, Ameryka i przyszłość światowej gospodarki, Warszawa 2015.

Weis T., Światowa gospodarka żywnościowa. Batalia o przyszłość rolnictwa, Warszawa 2011. 